\title{
Child Labor- A Study from Anthropological Perspective With Special Reference to Glass Industry, Firozabad
}

\author{
Anjuli Chandra \\ Department of Anthropology University of Allahabad, Allahabad 211 002, \\ Uttar Pradesh, India \\ E-mail: anjuli_c@rediffmail.com
}

KEYWORDS Child Labor. Glass Industry. IASP. ILO. Indebtedness. Poverty

\begin{abstract}
When children do any work out of their wishes then it is called child work but it is called child labor, when it is under compulsion. Child labor is a complex phenomenon that defies simple solutions. The present paper also focuses on this very problem of child labor but from anthropological perspective. The objective of the study is fourfold: firstly to define the concept of child labor and showing it's Indian and International scenario; secondly how and why children got engaged in this vicious cycle of bangle making and ultimately become a child labor; thirdly to explore the structural roots of the phenomenon and the problems faced by the child labor and their families; and finally the study presents anthropological perspective of the problem of child labor which clearly indicates that how child labor is intimately associated with the social, cultural, traditional and economic background of the people living in the area and facing the problems. The paper concludes with certain suggestive measures, which are more of preventive rather than of curative nature and are yet to achieve.
\end{abstract}

\section{INTRODUCTION}

Anthropology, science of man, encompasses all beliefs, customs, traditions, art, morals, practices, knowledge, etc which man acquired as a member of the society. The ultimate goal of anthropological studies is to make society a better place to live in, a society which is free from any kind of problems and with this aim in mind the present study explores the problem of child labor with an anthropological perspective, by elaborating the findings of an evaluation study of a social intervention project (of which the author was the part), for combating child labor engaged in glass industry of Firozabad in Uttar Pradesh, sponsored and launched by ILO.

According to the Encyclopedia of Social Sciences, it is defined as 'when the business of wage- earning or of participation in self or family support conflicts directly or indirectly with the business of growth and education, the result is child labor. The function of childhood is primarily developmental and not economic; Children's work then, as a social good, is the direct antithesis of child labor as a social evil'.

According to recent estimates of the International Labor Organization (ILO) there were

Mailing address:

Anjuli Chandra, 231, New Mumfordganj,

Allahabad 211 002. Uttar Pradesh, India

Mobile: 09415365822. about 352 million children aged 5-17 years in some form of economic activity in the world in 2000, including 211 million in 5-14 year's age group. Nearly 171 million children were engaged in various hazardous occupations. Of these children, 111 million children estimated below 15 years of age. The estimates also reveal that AsiaPacific region has the largest number of 127.3 million child workers in 5-14 years age group (ILO IPEC 2002).

The traditional explanation generally assigned for the existence of child labor includes three factors- societal attitudes, lack of compulsory education and poverty. Apart from the traditional explanations, another phenomenon of the 1980's and 1990's leading to dramatic increase in the number of working children lies in the Structural Adjustment Programme (SAP) facilitating the process of globalization. The SAP has been basically forced upon the developed nations by the IMF and World Bank as part of a package deal for being bailed out of the debt crisis. This mode of restructuring global economy with export- lead unrestricted forces of world markets is now resulting in casualization of labor, growing unemployment, poverty and social deprivation of the masses. In the face of severe debt crisis in developing countries, the first axe of the financial cuts falls on the social sector investments (Roy 1996). To make competitive advantage for their exports in the global market, children become the 
easiest targets for these countries. They are employed with very low wages when demand for export goods exist and when faced with slack in demand the helpless tiny tots can be easily laid -off without compensation (Bhatty 1996).

\section{Indian Scenario}

After a fall in number of working children during post independent India, it started growing again in late 1970, 1980 and 1990s when our political economy initiated structural changes towards globalization and consequently social sector investments experienced reductions and cuts in both planned and non-plan financial allocations. Net result of these changes may be observed from the fact how the number of child laborers increased over these years. According to 1971 census the estimated number of working children was 10.7 million, which swelled to 13.6 million in 1981, and the official census 1991 estimates put it to 11.2 million. However, the National Sample Survey Organization (NSSO) estimates record this number to 17.2 million for 1987-88. Unofficial estimates by some independent organizations and researchers, for 2001, suggest that the child labor population in the country ranges between 44 million to 110 million. These children work in various agricultural operations, assist in household work, work as artisans, as potters, blacksmith, rope making, basket weavers, handloom weavers, etc. In urban areas child labors are concentrated in the formal sectors and in small and cottage industries, tea stalls, restaurants, workshops, factories and work as domestic servants, rag pickers, carrying loads, etc. The States of Uttar Pradesh, Madhya Pradesh, Orissa, Andhra Pradesh, Karnataka and Tamil Nadu account for most of the child workers in India. Overwhelming majority of these children come from the families and communities of the poor including SCs, STs, OBCs, Minorities and landless agricultural laborer's household (Bhatt 2003).

\section{ILO: An International Initiative to Combat Child Labor}

The International Labor Organization (ILO) has always remained concerned with child labor issues from its very inception in 1919. One of the most important initiatives of ILO's technical cooperation activities on child workers has been its International Programme on Elimination of Child Labor (IPEC) launched in 1991. India became the first signatory to this initiative to combat and eliminate child labor progressively with the signing of MoU for ILO- IPEC in 1992 (ILO, 1999). This programme is a global initiative to support participating member countries in their national efforts to combat child labor progressively and simultaneously to create a worldwide movement against the evil. Altogether, ILO-IPEC as per its latest progress report implemented 175 action programmes in the country, directly rehabilitating and reducing the vulnerability of approximately 1,45,000 children working in hazardous occupations and processes during 1992- 2002 (ILO 2002a).

\section{FIELDAREA}

The area of study was the Firozabad district, situated in North-central India in Western Uttar Pradesh. The focus of the study was the bangle and glass industry of Firozabad, where according to the local observers; about 50,000 child workers are still engaged in this hazardous industry. Firozabad district is popularly known as the 'Glass City or Suhag Nagri' of India.

\section{Glass Industry Firozabad}

At present 700- glass manufacturing units are operated in the district as per local estimates. However, the official number of the registered units is reported as 437 . The products of the glass industry broadly include glass bangles, glass hardware, glass art wares, glass domestic wares, glass scientific and lab wares, glass automobilewares and glass street and domestic light wares. Primary glass and bangle manufacturing process are generally performed in industrial sheds of the district. For melting soda ash and silica sand in the pots, (the basic ingredients of the glass) the temperature inside the Bhattis (furnaces) is kept at about $1400^{\circ} \mathrm{C}-1600^{\circ} \mathrm{C}$ which increases ambient temperature inside the manufacturing sheds in the range of $45^{\circ} \mathrm{C}$ to $50^{\circ} \mathrm{C}$. Workers in a factory continuously work for 8- $12 \mathrm{hrs}$ per day under these conditions mostly standing very close to furnaces leading to several types of health hazards. 


\section{METHODOLOGY}

The main basis of findings relies on the participatory- observation method, which is regarded as a fundamental technique of data collection in anthropology. However, substantiated empirically at places by the findings of a post project evaluation study of social intervention for combating child labor engaged in glass industry of Firozabad (U.P.), sponsored and launched by ILO (International Labor Organization), of which author was the part, as a member of the investigating team. The methodology employed for conducting post project evaluation study involved all participants engaged with the activities in a participatory manner. The tools used in the study are mainly questionnaires, interview schedules, formal and informal meetings and interviews.

The method of random sampling is used for conducting the study. The samples for the different target groups covered under the project are as follows:

\begin{tabular}{lrr}
\hline $\begin{array}{l}\text { Target groups } \\
\text { of the project }\end{array}$ & $\begin{array}{l}\text { Sample } \\
\text { size }\end{array}$ & $\begin{array}{l}\text { Total } \\
\text { population }\end{array}$ \\
\hline $\begin{array}{l}\text { Sampled villages/ mohallas } \\
\text { Beneficiary households }\end{array}$ & $50(37 \%)$ & $135(100 \%)$ \\
& $528(20.6 \%)$ & $2567(100 \%)$ \\
$\begin{array}{l}\text { Mainstreamed children } \\
\text { (5-7) yrs }\end{array}$ & $427(8.9 \%)$ & $4794(100 \%)$ \\
$\begin{array}{l}\text { Schools where (5-7) yrs } \\
\text { children were Main }\end{array}$ & $32(21.6 \%)$ & $148(100 \%)$ \\
$\begin{array}{l}\text { streamed } \\
\text { Mainstreamed children }\end{array}$ & & \\
$\begin{array}{l}\text { admitted in } \\
\text { TECs (Transitional }\end{array}$ & & \\
$\begin{array}{l}\text { Educational Centers), } \\
\text { (8-12) yrs. }\end{array}$ & & \\
$\begin{array}{l}\text { Skill trainees (13-16) yrs } \\
\text { SHGs (Self Help Groups } \\
\text { formed by Mothers of } \\
\text { child labors) }\end{array}$ & $92(24 \%)$ & $392(100 \%)$ \\
\hline
\end{tabular}

Source: Data collected from the field.

Note: Figures in the parenthesis denote row percentage.

\section{FINDINGS OF THE STUDY}

Out of total household population working in formal and informal sectors $24.4 \%$ were child labor up to 16 years age at the beginning of IASP (Integrated Area Specific Project), while the proportion was found $26.3 \%$ at the time of field survey, recording a net increase of 1.9 percentage points instead of making a decline, compels one to think who were actually benefited as a result of awareness generation and material provisions of the project. It was found that the children not actually targeted and doing nothing took the advantage while not finding anything to work.

A remarkably high level of $135 \%$ increase was noticed in net enrollment level of so called 'street children' or 'no- where children' (belonging up to 12 years age group) as a result of IASP activities. As only 410 of the age group were attending schools before the programme while their number swelled to 962 after the project.

Evaluation study results show that only $79.2 \%$ of the mainstreamed 5-7 years children were regularly attending the schools; $7.7 \%$ were dropouts; and $13.7 \%$ attending schools very rarely.

Majority of $78.4 \%$ SHGs mothers were found illiterate; $45.2 \%$ were engaged in bangle and glasswork with their earning levels mostly varying between Rs. 11- 30 per day.

\section{Child Labor in Glass Industry}

Children are engaged into various processes of glass works as early as from the age of 5-6 years. Maximum number of child labor was found in the age group of 8-12 followed by 13-16.

The operations which involves child labor in maximum and are carried out in the informal sectors, outside the factory, at household levels and go downs includes Jhalai (straightening of bangles), Jurai (joining), Murai (designing by use of forceps), Katai (designing by grinders), Polishing by application of chemicals or liquid gold called Hil, Chaklai (sorting), packaging in small cardboard boxes, transporting the bangles from the place of one process to another. Working conditions in almost all these processes remain mostly injurious to health.

The socio- cultural background is the main factor for the cause of this social evil as people are deprived of basic education, the working conditions results into a number of health hazards and physical disabilities. As most of the work in the informal sectors is carried on as a family activity, children are involved in it very easily. In addition, they have no bargaining power like adult workers and they are more active, agile, quick, disciplined, do any kind of works without knowing if and buts of the consequences and less tiring to perform certain jobs.

On the other hand some of the child laborers are motivated to work because of monitory 
inducement which other working children gets. Even the school going children are attracted initially on part time basis and gradually joins the stream permanently.

Finally due to social and economic disparity their family become highly indebted and ultimately trapped into the vicious cycle of poverty and as such continued to be exploited more and more.

\section{Structural Roots of the Phenomenon of Child Labor}

The basic and main reason behind the problem is poverty, while the reason behind poverty is indebtedness. The process once started never ends and as a result the laborers enter into the vicious cycle of poverty. According to study, $93.5 \%$ of the bangle and glass worker households has taken loans during past 15 years; out of this, $50.2 \%$ had taken loans with exorbitantly high rate of annual interest varying between 40- 120\%; about $62.4 \%$ took loans simply for consumption purposes; main source for taking loans in case of $61.2 \%$ households was local money lenders.

In reply to a multiple response question on why people ask children to work, $87.9 \%$ households said that they want to supplement their low- income level with earnings of the children followed by $15.9 \%$ saying due to the compulsion of big family size and $11.2 \%$ engaged children due to non availability of agricultural land.

The factors like illiteracy of the parents, adult unemployment, and loss of head of the family and indifferent social attitude towards child work also push children to work.

Under these circumstances, despite of the fact that $96.8 \%$ respondents feel that engaging children in work is bad; $87.9 \%$ reported that children are forced to work due to their compulsions of supplementing household income for bare survival. In addition some other factors such as alcoholism among adults, low wage rates of adult workers, greediness, laziness and un- interest in doing works of parents, etc are also equally responsible for the evil.

\section{Problems Faced By the Child Labor}

First and foremost this state of child labor deprives children of their basic right to development hindering human resource development and disturbing there by the entire process of economic and social development.

Due to working as child labor they could not attend their schools regularly as several times they had to quit their schools because of heavy workload on the family which deprives them of their basic education.

The working conditions in which they work continuously for more than $12 \mathrm{hrs}$ either in the factory sheds or in the house hold is highly injurious for their health resulting in a number of health hazards such as; severe burn, cuts, stomach ache, headache, dizziness, loss in hearing power, weak eye sight, etc.

In addition due to lack of any technical/ joboriented education they suffer from the problem of unemployment in future.

Due to working and living in similar condition since childhood the mental set up and thinking of these child labors remain traditional and orthodox, as a result they have no other option but to compel their future generation also to work as child labor and thus the cycle continue generation after generation.

In this way the innocent and poor child labor and their family remain in the state of economic and social disparity in the society and continued to be exploited more and more both by the industrialists and the contractors engaged in bangle and glass industry of Firozabad.

\section{Anthropological Perspective of the Study}

Under this heading the study threw lights on certain observations, which clearly indicates that, how this social evil of 'child labor' is intimately associated with the social, cultural, economical, traditional and ecological background of the people facing the problems.

The socio- cultural condition was such that each and every person knows the consequences and even after knowing that child labor is an evil, which declines the growth of the society, they were compelled to do so, in order to sustain their livelihood. In addition, due to illiteracy and lack of awareness towards family planning programmes and contraceptive measures they have very large family size. The average number of members in a Muslim family ranges from 1214, while in a Hindu family it was 8-10. So, in both the cases the parents prefer to share the workload than to attend schools, for their children because 
they believed that in the later case the result will be nothing while in the former case they get something and something is always better than nothing.

In addition their economy was also very weak, they didn't have multiplicity of occupations as the ecological conditions were such that there was lack of agriculturally suited lands or water bodies for fisheries or any other basis of occupations. Under such conditions they didn't have any other option but to work as laborers and also compel their children to work on daily wages or on contractual basis. However, out of total households covered, some of them had other occupations like dairy, etc. but couldn't maintained it properly as it requires a good sum of monitory support.

Here one incidence important to mention is that during the project the womenfolk of the target group were given training in a number of small scale occupations such as pickle making, aggarbatti making, match stick and match box making, papad making, etc and were also promised by government officials for a matching grant, which was a sum of amount enough for starting any of these self employment based occupations. But the problem arises when they didn't receive this financial aid from the govt. and as such this entire training program become futile. In addition, women have to spend their own money for reaching to the training centers, which were fro off from their residential areas. This clearly indicates the inadequacy and improper functioning of government machinery. This indirectly affects the economy of these people and in turn enhances the cause of child labor.

Another point important to be highlighted is that, most of the households interviewed, were practicing this bangle and glass work since generations unknown and as such this whole occupation is deep rootly embedded in their tradition and culture. One of the observation that clearly substantiates the extent to which both the old as well as young ones were familiar to this occupation was " the children in one of the village of Narkhi block were seeing playing on the heaps of broken bangles so comfortably and easily and enjoying it also as much as with any other toys". This clearly shows that how the occupation of bangle and glass making is interwoven, intermixed and intermingled with the entire life of these peoples since periods unknown and this might be one reason that children get easily attracted to this occupation from their childhood only.

In this way, from above observations one comes to the conclusion that as an occupation for elders it is well and good. But when the children got involved and indulge into this occupation of bangle and glass making then only it becomes an evil, as it hinders the overall social and biological growth and development of these poor and innocent kids. Therefore, after knowing its social, cultural, economical and ecological aspects it should be and must be the duty of both the government and non-government organizations at least to prevent this evil from spreading more, if couldn't cure it completely.

\section{SUGGESTIVE MEASURES}

The problem of child labor has deep roots into a number of existing socio- economic and political processes and institutions. It cannot be treated in isolation. A holistic approach involving all can only bring the lasting solution. Therefore, some suggestive measures should be and must be taken; these are:

A continuous people's movement against child labor needs to sensitize the society about its cause and consequences. Apart from the elites and the corporate world, the movement requires careful support from the government and the local community.

So, in response to it an awareness program must be implemented and it should be totally based on motivation, free from any kind of monitory inducement.

It has become quite clear during the course of evaluation study that provision for good quality primary education and skill activities are essential to retain children in schools and prevent them from turning back to work in hazardous occupations.

For ensuring sustainability of working children's withdrawal from work, their families need immediate economic empowerment to compensate them for the financial loss.

Mobilization of support from various social, political and economic structures and institutions is of utmost importance for bringing effectiveness and efficiency in the implementation of such a project of social sector relevance on combating child labor.

The process of initial identification of child 
workers and their families become equally relevant to ensure assistance only to those who genuinely deserve it.

Mere introduction of newer and more schemes may not help. What is needed is to focus on an efficient implementation of existing schemes with better utilization of available resources. Even a well-planned and nicely documented project like ILO-IPEC (IASP), Firozabad may lead no-where, if not implemented with efficiency and thrust.

So, there should be a single line of administration without any mediators between the government and the target groups. Surprise checking and inspection also help to a great extent to solve the problem.

ILO's Firozabad experiment to provide a better world for the poor and helpless children working in the hazardous occupations indeed has been an appreciable effort. The project managed to successfully generate public demand for children's education to some extent. Group mobilization with meticulous planning, action and care, considering people's sensibilities, needs, aspiration, group dynamics and psychology, would be required to create a social movement against the issue in the district.

Anthropological perspective of the present study, infact gives a new picture to the problem of child labor by showing its social, cultural, economical, traditional and ecological factors responsible for the cause, which would certainly help government officials and in future if the plans and initiatives would be framed keeping all these factors in mind then it will definitely be a success. In the end, it could be said that despite poverty it can be possible to fight against child labor by generating an effective self employment base at the family, community and grass root levels and by motivating people to fight against the evil on their own without depending on any government or non- government organizations.

\section{REFERENCES}

Bhatt KN 2003. Integrated Area Specific Approach Against hazardous And Exploitative Forms of Child Labor in Firozabad: An Evaluation Report Sponsored by ILO under IPEC. Allahabad: G.B. Pant Social Science Institute.

Bhatty Kiran 1996. Child Labor Breaking the Vicious Cycle. EPW, February 17.

ILO 1999. International Program on Elimination of Child Labor in India, 1992-96. New Delhi: ILO Office.

ILO 2002A. Integration and Action Against Child Labor, 1992-2002: Achievements and Lessons Learnt. New Delhi: ILO Office.

ILO-IPEC 2002. Every Child Counts: New Global Estimates on Child Labor. Geneva: ILO-IPEC

Roy Arundhati 1996. Those That Be in Bondage: Child Labor and IMF Strategy in India. Foil, pamphlets1, fall. 